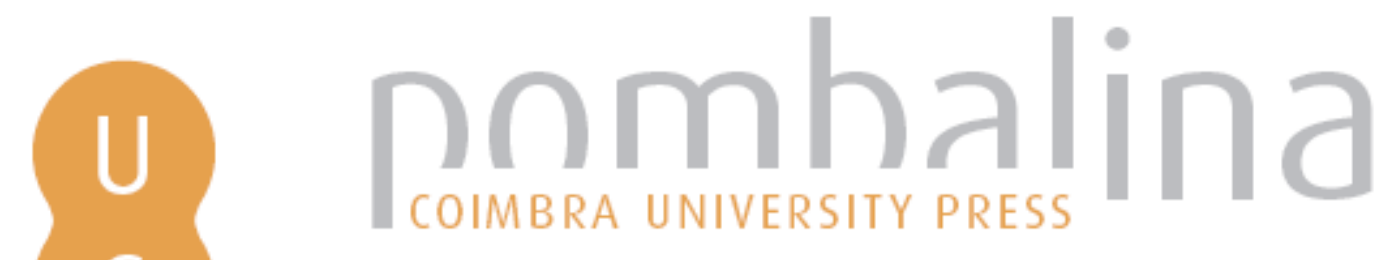

\title{
Dispositional forgiveness and gratitude among older people
}

\author{
Autor(es): $\quad$ Neto, Félix \\ Publicado por: Imprensa da Universidade de Coimbra \\ URL \\ persistente: URI:http://hdl.handle.net/10316.2/32544 \\ DOI: $\quad$ DOI:http://dx.doi.org/10.14195/978-989-26-0732-0_21
}

Accessed : $\quad$ 26-Apr-2023 16:17:06

A navegação consulta e descarregamento dos títulos inseridos nas Bibliotecas Digitais UC Digitalis, UC Pombalina e UC Impactum, pressupõem a aceitação plena e sem reservas dos Termos e Condições de Uso destas Bibliotecas Digitais, disponíveis em https://digitalis.uc.pt/pt-pt/termos.

Conforme exposto nos referidos Termos e Condições de Uso, o descarregamento de títulos de acesso restrito requer uma licença válida de autorização devendo o utilizador aceder ao(s) documento(s) a partir de um endereço de IP da instituição detentora da supramencionada licença.

Ao utilizador é apenas permitido o descarregamento para uso pessoal, pelo que o emprego do(s) título(s) descarregado(s) para outro fim, designadamente comercial, carece de autorização do respetivo autor ou editor da obra.

Na medida em que todas as obras da UC Digitalis se encontram protegidas pelo Código do Direito de Autor e Direitos Conexos e demais legislação aplicável, toda a cópia, parcial ou total, deste documento, nos casos em que é legalmente admitida, deverá conter ou fazer-se acompanhar por este aviso.

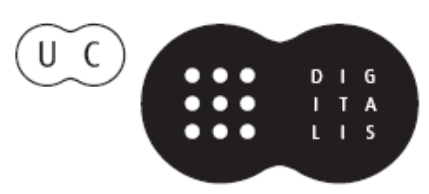


MPRENSA DA

UNIVERSIDADE

DE COIMBRA

COIMBRA

UNIVERSITY

- PRESS 


\title{
DISPOSITIONAL FORGIVENESS AND GRATITUDE AMONG OLDER PEOPLE
}

Félix Neto ${ }^{51}$

\begin{abstract}
This work analysed whether the three factors of forgivingness observed in adults - lasting resentment, sensitivity to circumstances, and unconditional forgiveness - were also present in older people. In addition, it examined whether gratitude accounted for a significant portion of the variance of dispositional forgiveness beyond that of socio-demographic variables. The sample comprised one hundred and nine old people (65 women and 44 men, mean age $=70.3$ years). The same three-factor structure that emerged in adults was also evidenced in older people. The expectation of (a) a negative correlation between lasting resentment, and gratitude, and (b) a positive correlation between unconditional forgiveness and gratitude was supported. Furthermore, results showed that gratitude explained a significant amount of variance of lasting resentment, and unconditional forgiveness.
\end{abstract}

Keywords: Forgiveness; Gratitude; Older people; Resentment.

A quick look at the handbook edited by Worthington (2005) is enough to demonstrate that, if much research has been performed among adults, by contrast the literature on older people is very scarce. Forgiveness is important to people of all ages; however, it seems that until recently researchers of forgiveness had prioritized college student participants

\footnotetext{
51 Universidade do Porto

Email: fneto@fpce.up.pt
} 
(Worthington, 2005). In the current study we will examine the relationships between forgivingness and gratitude among old people.

"No future without forgiveness" (Tutu, 1999). Indeed, forgiveness lubricates interpersonal and intergroup interactions (Neto, 2013). Forgiveness has been defined as the "forswearing of negative affect and judgment by viewing the wrongdoer with compassion and love, in the face of a wrongdoer's considerable injustice" (Enrigth \& the Human Development Study Group, 1991, p. 123). Forgivingness, dispositional forgiveness, has been defined by Roberts (1995) as "the disposition to abort one's anger (or altogether to miss getting angry) at persons one takes to have wronged one culpably, by seeing them in the benevolent terms provided by reasons characteristic of forgiving" (p. 290). Factorial studies, first conducted in France, have evidenced a three-factor model of forgivingness (Mullet et al., 2003): (a) Lasting resentment (an emotional component) expresses basic physiological reactions to the harmful situation; (b) Sensitivity to the circumstances (a cognitive component) can be considered as representing the "earthly" aspect of forgiveness, one that has no relationship to religious involvement (Akl \& Mullet, 2010); (c) finally, Unconditional forgiveness (a transcendental component) can be viewed as the product of a type of personal, spiritual growth that may be relatively independent of external influences (Neto \& Mullet, 2004; Paz, Neto, \& Mullet, 2007). According to Mullet, Neto, and Rivière (2005, p. 161) "it is essential to differentiate these concepts and measure the impact of different personality measures on each component".

Past empirical work has examined the relation between several socio-demographic variables and forgiveness, such as gender, age, educational level, and religious involvement (e.g., Mullet et al., 1998; Paz et al., 2007). Several investigations examined the effect of gender on forgiveness, and in general its role is very limited (Worthington, 2005). The effect of age on forgiveness has also been examined in previous research. For example, the propensity to forgive increased from adolescence to old age (Girard \& Mullet (1997). However, the present study included only old people. As most of the research about forgiveness has been conducted among college students the educational level rarely has been examined. However, in a previous study, individuals who had completed secondary education had 
higher scores on sensitivity to circumstances, and lower scores on lasting resentment than people who had not (Mullet et al., 1998). Past research has also shown a relationship between religious involvement and the following forgivingness constructs: lasting resentment and unconditional forgiveness (Mullet et al., 2003).

A variety of reasons why individuals forgive are advanced in the literature (Enright \& Fitzgibbons, 2000; Worthington, 2005). According to Munoz Sastre et al. (2005, p. 766) "these reasons range from very general personal-level ones (e.g., agreeableness), to relational-level ones (e.g., previous acquaintance with the offender) to psycho-attributional ones (e.g., perceived offender's repentance), to very concrete offense-related ones (e.g., cancellation of the consequences of the offense)". In the current study our interest directs to one general personal-level reason: gratitude.

McCullough, Emmons, and Tsang (2002, p. 112) defined "the grateful disposition as a generalized tendency to recognize and respond with positive emotions to the role of other people's benevolence in the positive experiences and outcomes that one obtains". In that research gratitude appeared related to prosocial characteristics. "The prosocial nature of gratitude suggests the possibility that the grateful disposition is rooted in the basic traits that orient people toward sensitivity and concern for others" (McCullough et al., 2002, p. 114). Given the prosocial nature of gratitude, a link with forgiveness could be expected.

A recent work sought to determine whether gratitude accounted for a significant portion of the variance beyond that of personality in the study of dispositional forgiveness (lasting resentment, sensitivity to circumstances, and unconditional forgiveness) among young adults (Neto, 2007). The findings supported that personality, particularly agreeableness and neuroticism correlate with lasting resentment and unconditional forgiveness. Additionally, results using multiple regression models indicated that gratitude explained a significant amount of variance of unconditional forgiveness.

In the present research we had three aims. The first aim was to identify whether the three factor structure of dispositional forgiveness emerged among older people. This structure should include the following factors: lasting resentment, sensibility to circumstances, and unconditional forgi- 
veness. The second purpose of the present research was to analyse the relation between socio-demographic factors and forgiveness. The third aim of this investigation was to examine whether gratitude adds a significant amount of explained variance to our understanding of forgivingness beyond socio-demographic variables.

In particular, three questions were posed: (1) how does forgiveness relate to socio-demographic factors, such as, age, gender, level of education, and religious involvement? The first hypothesis, based on previous research (Mullet et al., 2003) was that men and women would have similar scores in forgivingness. The second hypothesis was that a link should be found between the educational level and two forgivingness factors: sensitivity to circumstances and lasting resentment (Mullet et al., 1998). Our third hypothesis was that religious involvement variables should be linked to two forgivingness factors: lasting resentment, and unconditional forgiveness (Mullet et al., 2003). Religious involvement will positively predict unconditional forgiveness and negatively lasting resentment. Concerning sensitivity to circumstances, we did not advance any hypothesis. (2) How does forgivingness relate to gratitude? Our fourth hypothesis was that a relationship between forgivingness and gratitude should be found: lasting

resentment and unconditional forgiveness should be linked negatively and positively, respectively, with gratitude. (3) Does gratitude predict forgiveness, beyond socio-demographic factors? The fifth hypothesis was that gratitude would predict lasting resentment, and unconditional forgiveness beyond socio-demographic factors (Neto, 2007).

\section{Method}

\section{Participants}

There were 109 participants (65 women and 44 men). Ages ranged from 65 to 90 years. Mean age was $70.3(S D=5.8)$. Thirty eight per cent of the participants declared they had completed secondary education, $82 \%$ declared they believe in God, and $41 \%$ declared they attend church on a regular basis. 


\section{Material}

The material was composed of a questionnaire including:

(a) The Forgivingness Scale (Mullet et al., 2003). It was composed of 15 sentences expressing willingness to forgive under various conditions, five for each of the three factors. Examples of items are: "I feel unable to forgive even if the offender has begged for forgiveness" (Lasting resentment factor); "I feel it is easier to forgive once the consequences of the harm have been cancelled" (Sensitivity to circumstances factor); and "I can forgive easily even when the offender has not begged for forgiveness" (Unconditional forgiveness factor). An 11-cm scale was printed after each sentence. The two extremes of the scales were labelled completely disagree and completely agree.

(b) Participants completed also the Gratitude Scale (McCulough et al., 2002; Neto, 2007). This measure consists of six items. A sample item is: "If I had to list everything that I felt grateful for, it would be a very long list". Respondents rated their degree of agreement with the items using a five-point Likert-type scale (where $1=$ strongly disagree and $5=$ strongly agree). Higher scores indicate greater dispositional gratitude. Neto (2007) reported satisfactory psychometric properties in a Portuguese population. In the present study the coefficient alpha was .72.

(c) Furthermore, participants answered socio-demographic questions, such as age, gender, and educational level. Two additional questions were asked: "Do you believe in God?" and "Do you attend church every week (except when you are truly unable to do so)?"

\section{Procedure}

Recruitment and tests of the participants were performed by a trained psychology student in the Porto area, Portugal. The sample was recruited at a range of venues, including shopping centres and community groups. The research assistant was present when the participants filled in the questionnaires. The respondents completed 
the questionnaire in approximately 15 minutes. All participants were unpaid volunteers.

\section{Results}

Each rating by each respondent of the forgivingness questionnaire was converted to a numerical value expressing the distance (from 1 to 11) between the point on the response scale and the left anchor, serving as the origin. These numerical values were then subjected to statistical analyses.

An exploratory factor analysis was first performed. Using the scree test to identify the number of factors arising from this analysis, three factors emerged which accounted for $60.2 \%$ of the variance (Table 19). The first factor explained $36 \%$ of the variance and loaded items expressing Unconditional Forgiveness. The second factor explained $15.1 \%$ of the variance and loaded items expressing Lasting Resentment. The third factor explained $9.1 \%$ of the variance and loaded items expressing Sensitivity to Circumstances.

Table 19: Results of the Factor Analysis and Means and Standard Deviations on the Whole Sample

\begin{tabular}{|c|c|c|c|c|c|}
\hline \multirow[b]{2}{*}{ Items } & \multicolumn{3}{|c|}{ Factors } & \multirow[b]{2}{*}{$M$} & \multirow[b]{2}{*}{$S D$} \\
\hline & I & II & III & & \\
\hline $\begin{array}{l}\text { I can truly forgive even if the offender did harm } \\
\text { intentionally. }\end{array}$ & .65 & & & 5.39 & 3.49 \\
\hline I can forgive easily even if the offender has not & & & & & \\
\hline $\begin{array}{l}\text { begged for forgiveness. } \\
\text { I can truly forgive even if the consequences of }\end{array}$ & .93 & & & 4.50 & 3.62 \\
\hline harm are serious. & .86 & & & 4.75 & 3.55 \\
\hline $\begin{array}{l}\text { I can forgive easily even if the consequences } \\
\text { of harm have not been cancelled. }\end{array}$ & .80 & & & 5.50 & 3.37 \\
\hline I can easily forgive even when the offender & & & & & \\
\hline has not apologized. & 88 & & & 4.48 & 3.61 \\
\hline I do not feel able to forgive even if the consequences & & & & & \\
\hline of the harm have been cancelled. & & .68 & & 3.31 & 2.76 \\
\hline $\begin{array}{l}\text { I cannot forgive even if the consequences of } \\
\text { harm are minimal. }\end{array}$ & & .59 & & 3.69 & 3.09 \\
\hline
\end{tabular}




\begin{tabular}{|c|c|c|c|c|c|}
\hline \multirow[b]{2}{*}{ Items } & \multicolumn{3}{|c|}{ Factors } & \multirow[b]{2}{*}{$M$} & \multirow[b]{2}{*}{$S D$} \\
\hline & I & II & III & & \\
\hline has apologized. & & .81 & & 3.50 & 2.91 \\
\hline I feel unable to forgive even if the offender & & & & & \\
\hline has begged for forgiveness. & & .82 & & 3.50 & 2.99 \\
\hline $\begin{array}{l}\text { The way I consider the world has brought me } \\
\text { never to forgive. }\end{array}$ & & .59 & & 2.45 & 2.35 \\
\hline I forgive more easily if the offender has apologized. & & & .65 & 8.30 & 3.00 \\
\hline I forgive less easily when I feel bad. & & & .64 & 4.22 & 3.53 \\
\hline I can forgive more easily when I feel good. & & & .75 & 5.61 & 3.74 \\
\hline $\begin{array}{l}\text { I feel it is easier to forgive somebody I know well } \\
\text { than somebody I do not know well. }\end{array}$ & & & .70 & 6.03 & 4.00 \\
\hline $\begin{array}{l}\text { I feel it is easier to forgive once the consequences } \\
\text { of harm have been cancelled. }\end{array}$ & & & .64 & 7.13 & 3.34 \\
\hline Eigenvalue & 7.19 & 3.01 & 1.82 & & \\
\hline Variance & 35.96 & 15.07 & 9.12 & & \\
\hline
\end{tabular}

For each three factors a mean score was computed by averaging the corresponding item scores. Means, standard deviations by gender, and Cronbach's alphas for each forgivingness factor are presented in Table 20. The alpha values in the current study were .85 (Lasting resentment), .72 (Sensitivity to circumstances), and .91 (Unconditional forgiveness). Consistent with previous research (Mullet et al., 2003), no gender differences were found among the three forgivingness factors.

Table 20: Alpha Coefficients and Mean Scores by Gender for all Measures

\begin{tabular}{lcccc}
\hline & Alpha & Men - Mean $(S D)$ & Women - Mean $(S D)$ & $F$ \\
\hline Lasting resentment & .85 & $3.55(2.54)$ & $3.11(2.0)$ & 1.45 \\
Sensitivity to circumstances & .72 & $10.92(3.36)$ & $10.43(2.8)$ & .64 \\
Unconditional forgiveness & .91 & $4.50(3.1)$ & $5.21(2.0)$ & 1.45 \\
\hline
\end{tabular}

Note: ${ }^{*} p<0.05 ; * * p<0.01 ; * * * * p<0.001$.

Pearson product-moment correlation coefficients were conducted among the three subscales to examine the amount of convergence (Table 21). As expected, lasting resentment and unconditional forgiveness displayed a significant correlation. This result indicates a moderate overlap between the two subscales. There is also a negative correlation between sensitivity to circumstances and unconditional forgiveness. Finally, lasting resentment and sensitivity to circumstances were not significantly correlated. This 
pattern of correlations suggests that the three subscales are not assessing the same forgivingness facets.

Table 21: Intercorrelations Among Forgiveness Factors

\begin{tabular}{lccc}
\hline & 1 & 2 & 3 \\
1. Lasting resentment & -- & & \\
2. Sensitivity to circumstances & .01 & --- & \\
3 Unconditional forgiveness & $-.44^{* * *}$ & $-.23^{*}$ & --- \\
\hline
\end{tabular}

Note: ${ }^{*} p<0.05 ;{ }^{* *} p<0.01 ;{ }^{* * *} p<0.001$.

Table 22 shows the results of a correlational analysis computed between the participants' scores on the three forgivingness factors and some of the participants' characteristics. Age was only related to sensitivity to circumstances. Older participants tended to show higher scores in Sensitivity to Circumstances than younger participants. However, note that all participants were old people. Other significant relationships concerned unconditional forgiveness and educational level. People with a higher educational level tended to have lower unconditional forgiveness scores. Believers and people attending church on a regular basis showed higher scores in unconditional forgiveness and lower scores in lasting resentment. Furthermore, gratitude was related to unconditional forgiveness, and lasting resentment. Higher grateful tendency was associated with higher unconditional forgiveness and lower lasting resentment.

Table 22: Correlations Between Forgivingness Scores and Characteristics of the Participants

\begin{tabular}{lccc}
\hline Characteristics & $\begin{array}{c}\text { Lasting } \\
\text { resentment }\end{array}$ & $\begin{array}{c}\text { Sensitivity } \\
\text { to circumstances }\end{array}$ & $\begin{array}{c}\text { Unconditional } \\
\text { forgiveness }\end{array}$ \\
\hline Age & .09 & $.32^{* * *}$ & .09 \\
Gender & -.09 & -.08 & .12 \\
Education & .12 & -.15 & $-.28^{* * *}$ \\
Believer & $-.29^{* *}$ & -.03 & $.17^{*}$ \\
Church attendance & $-.29^{* *}$ & .15 & $.18^{*}$ \\
Gratitude & $-.45^{* * *}$ & -.07 & $.35^{* * * * *}$ \\
\hline
\end{tabular}

Note: ${ }^{*} p<0.05 ; * * p<0.01 ; * * * *<<0.001$. 
Three hierarchical regressions were conducted to examine whether gratitude predicted the forgivingness factors beyond the socio-demographic characteristics (gender, age, educational level, belief in God, and church attendance) (Table 23). Variables were entered into the hierarchical multiple regression analysis in two steps. In the first step, the five socio-demographic factors were entered. In the second step, the gratitude score was added. For lasting resentment, in step one, church attendance explained a significant amount of the variance. In step two, gratitude provided a significant amount of additional explained variance. For sensitivity to circumstances, in step one, age explained a significant amount of the variance. In step two, gratitude did not provide a significant amount of additional explained variance. For unconditional forgiveness, in step one, educational level and church attendance explained a significant amount of variance. In step two, the gratitude score provided a significant amount of additional explained variance of unconditional forgiveness.

Table 23: Hierarchical Multiple Regression Analyses Examining the Prediction of Forgiveness by Demographic Factors (step 1), and Gratitude (step 2)

\begin{tabular}{lcccc}
\hline & Step 1 & Step 2 & Step 1 & Step 2 \\
& Std $\beta P$ & $\begin{array}{c}\text { Std } \beta P \\
\text { Lasting resentment }\end{array}$ & $\begin{array}{c}\text { Std } \beta P \\
\text { Sensitivity to circumstances }\end{array}$ \\
\hline Step 1 & & & & \\
Gender & .05 & .05 & -.10 & -.11 \\
Age & .08 & .04 & $.28^{* * * *}$ & $.28^{* * *}$ \\
Educational level & .11 & .08 & -.15 & -.15 \\
Belief in God & .18 & .13 & .01 & .01 \\
Church attendance & $.24^{*}$ & .15 & -.10 & -.09 \\
Step 2 & & & & .07 \\
Gratitude & & $-.37^{* * * * *}$ & & $.08^{*}$ \\
$\mathrm{R}^{2}$ & $.06^{*}$ & $.14^{* * * *}$ & $.08^{*}$ & \\
\hline Step 1 & Unconditional forgiveness & & \\
Gender & & & & \\
Age & .08 & .06 & & \\
Educational level & .11 & .15 & & \\
Belief in God & $-.28^{* *}$ & $-.25^{*}$ & & \\
Church attendance & -.12 & -.03 & & \\
Step 2 & $-.21^{*}$ & $-.13^{*}$ & & \\
Gratitude & & & & \\
$\mathrm{R}^{2}$ & & $.34^{* * * * *}$ & & \\
\hline
\end{tabular}

Note: ${ }^{*} \mathrm{p}<0.05 ;{ }^{* *} \mathrm{p}<0.01 ;{ }^{* * *} \mathrm{p}<0.001$. 


\section{Discussion}

The current research approached forgivingness (dispositional forgiveness) among older people. The first purpose was to identify whether the three-factor structure that emerged in adults was also in place in older people. We also observed this. These findings were consonant with past investigation (Munoz Sastre et al., 2005; Mullet, Rivière, \& Munoz Sastre, 2006). Those samples, however, were described as largely composed of young adults and adults. By contrast, in the current study the sample consisted of older people.

The second purpose of the current study was to link the observed factorial structure with socio-demographic characteristics of the participants. Past investigation has evidenced that old individuals in general forgive more than young individuals (e.g., Girard \& Mullet, 1997; Mullet et al., 2003). Nevertheless, participants in the present work consisted only of older persons and within this age range a relationship between age and forgivingness was limited to the sensitivity to circumstances factor. The scores of this factor increased with age among older people. Education did correlate significantly with unconditional forgiveness: the more educated the respondents, the less they displayed unconditional forgiveness. Our second hypothesis was not confirmed as the lasting resentment and sensitivity to circumstances factors were not related to educational level, in contrast with previous findings (Mullet et al., 1998).

We expected that religious involvement would be linked positively to unconditional forgiveness, and negatively to lasting resentment. This expectation was confirmed by the data. These findings are consonant with Mullet et al.'s (2003) results. Participants who believe in God and attend church on a regular basis showed more unconditional forgiveness than participants who do not believe in God and do not attend church. Furthermore, participants who believe in God and attend church on a regular basis declared less enduring resentment than participants who do not believe in God and do not attend church.

This investigation also intended to scrutinize the relations between forgivingness and gratitude. Our hypothesis was that of (a) a negative 
correlation between lasting resentment and gratitude, and (b) a positive correlation between unconditional forgiveness and gratitude. This is what was observed. Furthermore, gratitude predicted lasting resentment, and unconditional forgiveness beyond socio-demographic variables. These findings add to past investigation of the grateful disposition in predicting the propensity to forgive beyond socio-demographic predictors.

This study has several limitations. First, the design of this study consisted of cross-sectional sampling of the population. No causal inferences should be made from the data. Second, generalisations of these findings to settings different from ours should proceed cautiously. Future investigation is needed to better elucidate how gratitude influences the process of forgiveness.

\section{References}

Akle, M., \& Mullet, E. (2010). Forgivingness: Relationships with conceptualizations of divine forgiveness and childhood memories. The International Journal for the Psychology of Religion, 20, 1-14.

Enright, R. D., \& Fitzgibbons, R. P. (2000). Helping clients forgive: An empirical guide for resolving anger and restoring hope. Washington: A.P.A.

Enrigth, R. D., \& the Human Development Study Group. (1991). The moral development of forgiveness. In W. Kurtines \& J. Gewirtz (Eds.), Handbook of moral behavior and development, Vol. 1 (pp. 123-152). Hillsdale, NJ: Erlbaum.

Girard, M., \& Mullet, E. (1997). Propensity to forgive in adolescents, young adults, older adults, and elderly people. Journal of Adult Development, 4, 209-220.

McCullough, M., Pargament, K. I., \& Thorensen, C. (Eds.) (2000). Forgiveness: Theory, Research, and Practice. New York: Guilford.

McCullough, M.E., Emmons, R. A., \& Tsang, J. (2002). The grateful disposition: A conceptual and empirical topography. Journal of Personality and Social Psychology, 82, 112-127.

Mullet, E., Azar, F., Vinsonneau, G., \& Girard, M. (1998). Conhece-se pouco acerca do perdão. Psicologia, Educação e Cultura, II, 281-293.

Mullet, E., Barros, J., Frongia, L., Usai, V., Neto, F., \& Shafighi, S. (2003). Religious involvement and the forgiving personality. Journal of Personality, 71, 1-19.

Mullet, E., Houdbine, A., Laumonier, S., \& Girard, M. (1998). Forgivingness: Factor structure in a sample of young, middle-aged, and elderly adults. European Psychologist, 3, 289297.

Mullet, E., Neto, F., \& Rivière, S. (2005). Personality and its effects on resentment, revenge, and forgiveness and on self-forgiveness. In Worthington, E. L. (Ed.), Handbook of Forgiveness (pp. 159-182). New York: Routledge. 
Mullet, E., Rivière, S., \& Muñoz Sastre, M. T. (2006). Relationships between young adults' forgiveness culture and their parents' forgiveness culture. Journal of Cultural and Evolutionary Psychology, 4, 159-172.

Muñoz Sastre, M. T., Vinsonneau, G., Chabrol, H., \& Mullet, E. (2005). Forgivingness and the paranoid personality style. Personality and Individual Differences, 38, 765-772.

Neto, F. (2007). Forgiveness, personality and gratitude. Personality and Individual Differences, 43, 2313-2323.

Neto, F. (2013). Estudos de Psicologia Intercultural: Nós e outros, vol. 2. Lisboa: Fundação Calouste Gulbenkian.

Neto, F., \& Mullet, E. (2004). Personality, self-esteem, and self-construal as correlates of forgiveness. European Journal of Personality, 18, 15-30.

Neto, F., Pinto, M. C., \& Mullet, E. (2007). Intergroup forgiveness: East Timorese and Angolan perspectives. Journal of Peace Research, 44, 711-729.

Paz, R., Neto, F., \& Mullet, E. (2007). Forgivingness: Similarities and differences between Buddhists and Christians living in China. International Journal of Psychology of Religion, $17,289-301$.

Roberts, R. C. (1995). Forgivingness. American Philosophical Quarterly, 32, 289-306.

Tutu, D. M. (1999). No future without forgiveness. New York: Doubleday.

Worthington, E. L. (Ed.).(2005). Handbook of forgiveness. New York : Routledge. 